\title{
BOOK- REVIEW
}

Book: Economics of Kautilya, Shukra and Brihaspati

Author: Dr. B.R. Gewali

Publisher: Gyanjyoti Prakashan, Rundhati Trust, Manigram, Rupandehi, 2012

ISBN: 978-9937-2-4888-4

Pages: $102+$

Price: NRS. 120

Language: English

The book itself offers a key to open the lock of treasure of oriental economics. It gives us ideas that ancient economic thoughts are very rich and are still relevant in the present context. Credit does not go to a single stage for building an entire oriental economic system; each and every stage adds a stone in making the system prosperous and scientific. The root of oriental economic ideas goes back to human civilization. As time passed, different scholars have developed their economic insights as a product of their experience and utmost prudence. Their ideas were applied by rulers and emperors in order to make the country self-dependent and strong. As Adam Smith, Alfred Marshall and J.M Keynes lead to modern mainstream economics, Kautilya, Shukra and Brihaspati are recognized as the oriental economists.

After Adam Smith's publication of his second book and long tradition of contribution of classical economist in the world economy, the mainstream economy gained a tremendous progress. With the invention of science and technology and their collaboration with the principles of economic ideas and state affairs, the face of the world has drastically changed. This pulled the attention of the new generation. But few of the scholars were inclined to find facts about ancient economic ideas. Ancient economic ideas are contained in the oldest treatises like Veda, Upanishads, Smritis and Purans. Gradually oriental economic ideas were researched, modified and enriched by various teachers of various schools for the welfare of general public. Ideas served by ancient scholars are lofty in comparison to main stream modern economists.

Chapter one of the book under review opens the historical linkage of oriental economic thoughts traced back to Vedic era. Source of oriental economic thoughts are presented in this chapter with sufficient proof. The information on oriental economics is found scattered in various places such as-

a. Vedas, Upanishads, Smritis and Puranas

b. Ramayana and Mahabharata.

c. Brihaspati- Sutra

d. Shukra-niti 
e. Kautilya Arthashastra

f. Bouddha and Jain Scriptures

Chapter two elaborates the definitions and methods of oriental economics. Kautilya and Shukra hold the view of economics as follows:

- Human profession is economic activity which should not contrast tradition, belief and law of society.

- Land use for agriculture and settlements are the source of income for individual as well as for state. Thus, agriculture was the main stay of economics.

- Economics is the study which treats the method of getting return from these sources and concerns itself with the increase of sources.

- Economics is also related with political administration.

The definitions given by Kautilya and Shukra are production oriented whereas mainstream modern definitions are consumption oriented. Moreover, Kautilya's Arthashantra explains methodological steps used to complete a thesis in ancient times at Taxila University. Kautilya has used thirty two methods to complete his treatise.

Chapter three highlights the system of agriculture, animal farming and forest resource in ancient times. The pillars of the economy were agriculture, animal farming and commerce. The main sources of government revenue were arable land, economic forest and animal farming. Agriculture laborers were given wages according to their standard of living. The status of farmer was legally high.

Chapter four explains about trade and commerce. Ancient economists have given high importance to nation's economic prosperity. They focused mainly on government owned business enterprises. They have explained about development and regulation. Traders were given high priority by providing them national security. Consumer's security and price stability was also equally guaranteed. Nepal was also one of the partners of foreign trade. Nepalese woolen clothes and bitumen were famous in Magadha.

Chapter five pinpoints the pricing policy of goods. Price theory is the anchor of economics. The great teacher Shukra stated that the market prices move upward only because of the wicked policies of the king. The cost of production was the basis of long run price determination. In the short run, market price and value of the commodity may be different. The difference depends on availability and non-availability effect. The share of land in the national income was considered to be 16.67 percent. Similarly labour contributed by 58.33 percent. Capital contributed by 15 percent and entrepreneur contributed by 10 percent in national income. The percentage of national saving would be 16.67 . 
Chapter six focuses on government finance. Ancient economists had paid supreme importance for rich treasury- the kosa. Tax was one of the sources of government revenue. The other sources were land and industry. Public welfare was the main objective of tax collection and utilization. The Tax officer's behavior was sensibly deciphered as they should be honest in duty and humble towards tax payers. The righteously earned wealth would facilitate disciplined and peaceful self administration of the state.

Chapter seven is concluding section. Material prosperity, consumer's protection, system of four Varnas and Asharams are colourfully woven in a garland of oriental economic thought. The oriental economics ideas are enriched by the introduction of Tri- Varga balance which is explained so scientifically as general equilibrium in the modern economics. The book gives some spaces for the Nepalese products and places those maintained in Borhaspatya School. The author opines that it is surprising to see deep insight into the economic solution in Kautilya and Shukra. Theories propounded by those great teachers were tested, revised and applied by the society for long. In the context of agriculture development, price stability and government finance, ideas of Kautilya and Shukra are more practical than those of mercantilists, physiocrats and classicists.

In totality the book at hand is a useful capsule that narrates oriental economic system in an interesting manner. It seems that we are studying a fairy- tale of utopian era. But soon, the author's book brings us down to the reality providing enough resources and citations. The book is lofty and fantastic to the readers, researchers and policy makers.

\section{Baikuntha Pandey}

Teacher

Butwal Multiple Campus, Butwal

Tribhuvan University. 